\title{
Author Correction: A phenotypic and genomics approach in a multi-ethnic cohort to subtype systemic lupus erythematosus
}

\author{
Cristina M. Lanata (D), Ishan Paranjpe, Joanne Nititham, Kimberly E. Taylor, Milena Gianfrancesco, \\ Manish Paranjpe, Shan Andrews, Sharon A. Chung, Brooke Rhead, Lisa F. Barcellos, Laura Trupin, Patricia Katz, \\ Maria Dall'Era, Jinoos Yazdany, Marina Sirota \& Lindsey A. Criswell
}

Correction to: Nature Communications https://doi.org/10.1038/s41467-019-11845-y, published online 29 August 2019.

In the original version of this manuscript, in the discussion section in the seventh paragraph, the gene symbol for $P A R P 14$ was incorrectly given as PAR14 and incorrect citations of the literature were given. The incorrect version read 'We would like to highlight variants in $H L A-F, P A R 14$ and GAB2 controlled methylation sites in USP35. HLA-F is part of the nonclassical HLA-Ib genes, which are mono- or oligomorphic ${ }^{46}$. Surface expression of $H L A-F$ has been demonstrated on activated T, B and NK cells, and serum IgG autoantibodies against HLA-F have been detected in SLE patients and correlated with disease activity ${ }^{63-65}$. PARP14 encodes for poly (ADP-ribose) polymerase (PARP) protein family 14 and is involved in cellular maintenance and cell fate decisions, such as cell-cycle progression, metabolic pathways and ribosome biogenesis ${ }^{66}$. Its role in SLE and autoimmune disease has not been defined but it has been shown to regulate glycolysis via IL-4 in B lymphocytes ${ }^{67}$ and to promote survival of cancer cells ${ }^{67-69}$.'

The correct version replaces these sentences with 'We would like to highlight variants in HLA-F, PARP14 and GAB2 controlled methylation sites in USP35. HLA-F is part of the nonclassical HLA-Ib genes, which are mono- or oligomorphic ${ }^{46}$. Surface expression of $H L A-F$ has been demonstrated on activated T, B and NK cells, and serum IgG autoantibodies against HLA-F have been detected in SLE patients and correlated with disease activity ${ }^{63-65}$. PARP14 encodes for poly(ADP-ribose) polymerase (PARP) protein family 14 and assists in post-translational ribosylation modification of target proteins. Its role in SLE and autoimmune disease has not been defined but it has been shown to regulate glycolysis via IL-4 in B lymphocytes ${ }^{66}$, promote survival of cancer cells ${ }^{67}$, and regulate macrophage $\operatorname{activation}^{68}$.'

Further, the original refs. ${ }^{66-69}$ were replaced with the following corrected refs. ${ }^{66-68}$ and all following references were renumbered.

All of these errors have now been corrected in the HTML and PDF versions of the article.

\section{References}

66. Cho, S. H. et al. Glycolytic rate and lymphomagenesis depend on PARP14, an ADP ribosyltransferase of the B aggressive lymphoma (BAL) family. Proc. Natl. Acad. Sci. USA 108, 15972-15977 (2011).

67. Iansante, V. et al. PARP14 promotes the Warburg effect in hepatocellular carcinoma by inhibiting JNK1-dependent PKM2 phosphorylation and activation. Nat. Commun. 6, 7882 (2015).

68. Iwata, H. et al. PARP9 and PARP14 cross-regulate macrophage activation via STAT1 ADP-ribosylation. Nat. Commun. 7 , 12849 (2016). 
(c) (i) Open Access This article is licensed under a Creative Commons Attribution 4.0 International License, which permits use, sharing, adaptation, distribution and reproduction in any medium or format, as long as you give appropriate credit to the original author(s) and the source, provide a link to the Creative Commons license, and indicate if changes were made. The images or other third party material in this article are included in the article's Creative Commons license, unless indicated otherwise in a credit line to the material. If material is not included in the article's Creative Commons license and your intended use is not permitted by statutory regulation or exceeds the permitted use, you will need to obtain permission directly from the copyright holder. To view a copy of this license, visit http://creativecommons.org/licenses/by/4.0/.

(C) The Author(s) 2020 